\title{
Oral Mucosa- Gate for COVID-19 Infection and Correlation with Chemical Structures of the Biocides
}

\author{
KAMEL EARAR ${ }^{1}$, MANUELA ARBUNE ${ }^{1 *}$, OVIDIU SCHIPOR $^{1}$, \\ CARMEN MIHAELA DOROBAT ${ }^{2}$, VICTORITA STEFANESCU ${ }^{1 *}$, \\ GABRIELA GURAU ${ }^{1 *}$, LUCIAN LAURENTIU INDREI ${ }^{3}$, IULIU FULGA ${ }^{1}$, \\ LILIANA LACRAMIOARA PAVEL ${ }^{1 *}$, CRISTIAN - LEVENTE GIUROIU ${ }^{4}$ \\ ${ }^{1}$ Dunarea de Jos University, Medicine \& Pharmacy Faculty, 47 Domneasca Str., Galati, 800008, Romania \\ ${ }^{2}$ Infectious Diseases Hospital "Sf. Parascheva" Iași, 2 Octav Botez Str., 700116, Iasi, Romania \\ ${ }^{3}$ Grigore T.Popa University of Medecine and Pharmacy, Faculty of Medecine, 16 Universitatii Str., 70015, Iasi, Romania \\ ${ }^{4}$ Grigore T. Popa University of Medicine and Pharmacy, Faculty of Dental Medicine, 16 University Str., 700115, Iasi, \\ Romania
}

\begin{abstract}
The oral mucosa is a mirror of the state of health for the whole organism, representing a natural barrier to infection, an entry gate for a large number of pathogens, a site for microbial multiplication and for initiating disease-specific pathological processes, expressed by lesions, signs and symptoms characteristic for diagnosis. The new global threat to public health, COVID19 infection can be customized within the oral pathology. The new SARS-CoV-2 coronavirus is characterized by high contagiousness, airborne transmission, directly through inhaled drops or, indirectly, through the use of contaminated objects. The survival of the virus on surfaces, depending on their structure, varies from 4 hours to 9 days. The initiation of infection is possible through the binding of viruses in site of host cells, due to receptor affinity and an angiotensin converting enzyme (ACE2), distributed in the epithelium, alveoli, ascular endothelium, lung pneumocytes and macrophage. The severity of the infection varies from asymptomatic forms to severe complications, with high motility. In the absence of a treatment or vaccine with proven efficacy, to be approved for use in practice, prevention is limited to respecting hygiene and social spacing, proper use of protective equipment and limiting services and procedures at risk of dispersing aerosols and saliva.
\end{abstract}

Keywords: oral pathology, SARS-CoV-2, transmission, prevention

\section{Introduction}

Oral mucosa is a mirror of the state of health, representing a natural barrier to infection, an entry gate for a large number of pathogens, a site for microbial multiplication and for initiating diseasespecific pathological processes, expressed by lesions, signs and characteristic symptoms for diagnosis. The implications of the current COVID-19 epidemic in oral pathology are still little known, the research in this field being limited by the novelty of the etiological agent and the insufficient observation time since the outbreak of this phenomenon.

\section{Epidemiology COVID-19}

The COVID-19 epidemic, which started in China in early December 2019, has spread to the pandemic, on January 30, 2020 being declared by the World Health Organization as a "global emergency" for public health. Until March 31, most countries of the world were affected, with 781046 confirmed infected persons, of which 37205 deaths [1].

The etiological agent of the emerging COVID-19 infection, referred to as "SARS-CoV-2", has been identified and analyzed phylogenetically [2]. Coronavirus SARS-CoV-2 is part of the order Nidovirales, family Coronaviridae, genus $\beta-\mathrm{CoV}$, having an RNA genome. Nucleotide sequences of

*email: manuela.arbune@ugal.ro,victorita_stefanescu@yahoo.com,gabriela.gurau@ugal.ro,doctorpavel2012@yahoo.com 
SARS-CoV-2 are similar to other coronaviruses of the same genus responsible for previous emerging human epidemics, having approximately $80 \%$ similarity with SARS-CoV and 50\% with MERS-CoV [3]. Phylogenetic analysis indicates the zoonotic origin of SARS-CoV-2 from the bat, via an intermediate host, most likely pangolin [4].

The SARS-COV-2 structure consists of a nucleocapsid with a single stranded RNA core and a spherical lipoprotein envelope, with protruding spike shape proteins, which are attaching to the ACE2 receptors of the human cells to be infected [2].

So far, it is not approved for use any preventive vaccine or a treatment with proven efficacy and safety.

Clinical characteristic expresses a viral pneumonia with fever, cough, myalgia and asthenia and private imaging changes, but hemoptysis, headache, diarrhea, may participate in other events, less frequently [5]. In isolated cases, various neurological manifestations have been reported, such as encephalitis, neuritis, polyradiculonevritis [6]. Pneumonia COVID - 19 may develop severe respiratory distress, sepsis, and even death, being reported fatality rates between $5.8 \%$ and $0.7 \%$ [7].

However, approximately $80 \%$ of infections are forms asymptomatic or mild, many of them being diagnosed, contributing to the rapid spread of the population [8].

Transmission of the new coronavirus is usually directly on the airway by inhalation of droplets from the respiratory secretions of a sick person produced by coughing or sneezing, and the contact of the mucosa (oral, nasal or ocular) with the hands and the contaminated objects.

Transmission can also be done through the saliva of infected, symptomatic or asymptomatic persons.

The incubation time varies from 1 to 14 days, but can be extended up to 24 days. The virus was shown in respiratory secretions from 1-2 days before the onset of symptoms until it has more than 37 days debut/onset [9].

It is estimated that $48-62 \%$ of infections are transmitted during the pre-symptomatic period [10].

The replication cycle of SARS-CoV-2 is associated with the cytopathic effect, manifested by cellular lesions and increased apoptosis. Cell death triggers an inflammatory response, which results in local clearance of the virus. Sometimes this response is uncontrolled, accompanied by immune cell proliferation and cytokine overproduction with severe systemic effects.

Antibodies IgM and IgG anti-SARS-CoV-2 appear after 6-15 days of the onset protection level, and the duration of immunity is not yet defined the risk of reinfection [11].

The main interventions for mitigation of the epidemic is limited to compliance with hygiene measures, travelling restriction, social distancing, quarantine of those exposed and isolation of people with suspected symptoms of the disease. This context has major implications in the medical field, but also within psychological, social, economic or administrative fields. Strategies for public health consider specific recommendations for different medical specialties.

\section{Particularities of COVID-19 in oral medicine}

The highest risk for transmission of SARS-CoV-2 associated with healthcare, both for patients and for medical staff, especially during epidemic periods, is attributed to the specialties of dental medicine and auto-rhinolaryngology.

The procedures specific to these specialties involve face-to-face communication, often at short distances, with prolonged exposure to saliva, blood, other biological products and invasive instrumentation [12].

The virus dispersed during speech, cough or sneeze particles can persist for a long time in suspension in the ambient air and can be transmitted by inhalation or contact with the object contaminated holders. At room temperature, SARS-CoV-2 persists on surfaces (inanimate surfaces) over 9 days, but the duration of survival depends on the structure of the objects. Aluminum and copper allow survival for several hours, stainless steel and plastic for 2-3 days, ceramics 5 days, and paper and glass over 5 days [13]. 
Odor and taste disorders were reported with frequency of $85.6 \%$ and $88.0 \%$, respectively, especially in patients in Europe. The characteristics of these dysfunctions are the early onset and the reversible evolution, being the only manifestations of the disease, with value for diagnosis [14].

The pathogenesis of COVID-19 involves the binding of surface viral proteins to the angiotensin converting enzyme (ACE2) receptors, whose presence in the respiratory tract has been proven.

ACE2 receptors have also been shown on the surface of epithelial cells in the structure of salivary glands, gingival tissue and tongue, but their affinity for SARS-CoV-2 and the influence on infectious pathogenic mechanisms are to be studied [15].

The expression of ACE2 receptors is determined by the ACE2 gene, located on the X chromosome, which may explain the differences in susceptibility to SARS-CoV-2, with higher severity of infection in men than in women. Modulation of ACE2 expression is also influenced by nicotine exposure, explaining the increased risk of smokers for severe forms of COVID-19 [16-18].

The hypotheses regarding the impact of SARS-CoV-2 on the oral mucosa and the understanding of the individualized response of this infection may take into account the particularities of the oral microbiota, the flow and the quality of the saliva in relation to the pathology of the salivary glands, the specific immunological response of genetic factors, age, co-morbidity, morbidity and morbidity or the chronic use of co-morbidities.

These data may support the role of the oral mucosa for transmission and pathogenesis of SARSCoV-2, which may originate in saliva from infected salivary glands, sputum and blood via the shrinkage fluid. Research to find salivary and agnostic biomarkers could optimize virus detection [1921].

\section{Oral medical services in the context of COVID-19}

COVID-19 infection can be transmitted during oral procedures, both to patients and to medical staff.

The principles of standard precautions require the treatment of any patients as potentially infected, with the utmost attention being given to strict hand hygiene, surface disinfection and the use of protective equipment, with masks, gloves, gowns, goggles or face shields [22-24].

However, the usual protective measures have proved insufficient for the prevention of COVID-19, especially in the case of oral treatments in asymptomatic patients or those who do not report their disease. There is no consensus on when further activities continue in oral medicine during a pandemic, but many affected countries have adopted temporary suspension of dental appointable service, limited to emergency response with recommendations for careful assessment of risk of each patient, to avoid aerosol generating procedures or their replacement of intraoral dental radiographs with other external imaging procedures [12].

\section{Prevention of COVID-19 infection in the practice of oral medicine}

Many countries have taken in the world the suspended temporarily activity in clinics dedicated to oral pathology. The safety of the whole medical act requires a review of the usage and guides for practice in oral medicine, with reference to the protection equipment, protection protocols for disinfection, the type of biocides approved and recommendation procedures with minimal impact on the production of aerosols.

The standards required for the disinfection of instrumentation, surfaces, air and hand hygiene are aimed at the use of biocidal substances and for SARS-CoV-2.

Hand hygiene with soap and water is the most popular way to prevent COVID-19 infection, both by mechanical removal and by altering the viral integrity. The hydrophobic fraction of the soap has affinity for the lipid structure of the lipoprotein envelope which is disintegrated, followed by the incorporation of the resulted particles into the mycelium (Figure 1). 


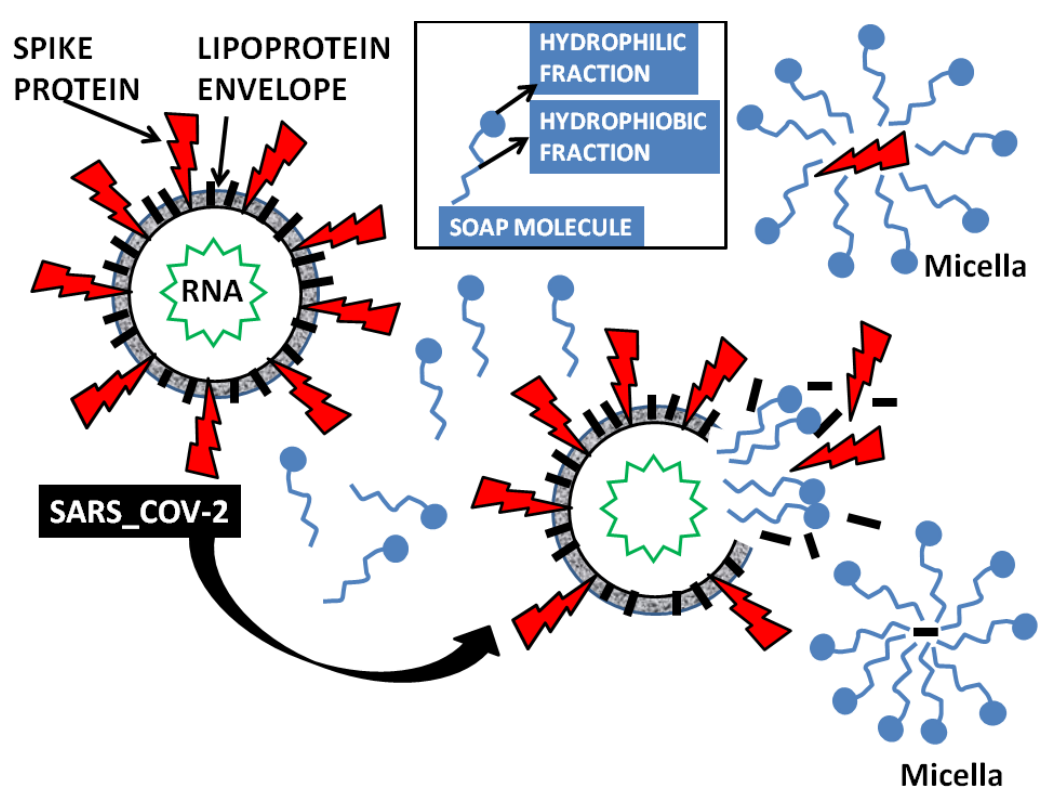

Figure 1. A probable interaction mechanism of soap and SARS-COV-2 adapted from: Ferris Jabr. Why soap Works? The New York Times. March 13, 2020 https://www.nytimes.com/2020/03/13/health/soap-coronavirus-handwashing-germs.html

To date, no substance with specific biocidal efficiency for SARS-CoV-2 is certified, the current recommendations being based on the results of studies on other coronaviruses. Surface cleaning uses decontamination with a neutral detergent, washing with water and decontamination with sodium hypochlorite solution with a concentration greater than $0.21 \%$ [25].

Different concentrations of biocidal substances are tested for inactivation of coronaviruses, including ethanol (78-95\%), 2-propanol (70-100\%), 2-propanol 45\% and 1-propanol 30\%, glutaraldehyde (0.5-2.5\%), formaldehyde (0.7-1\%) and povidone iodine (0.23-7.5\%) (Figure 2).

The best results were obtained with ethanol at concentrations of $62-71 \%$, exposed for 1 minute [13].

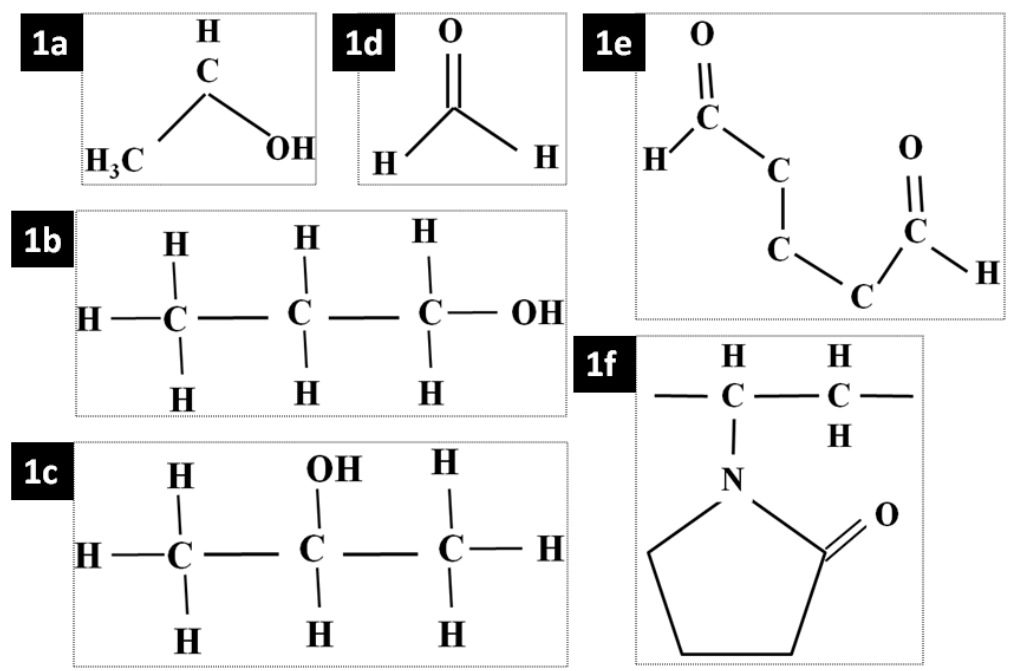

Figure 2. Biocide substances used for SARS-COV-2 inactivation

1a:Ethanol; 1b:1-Propanol; 1c: 2-propanol; 1d:Glutaraldehyde; 1e:Formaldehyde;

1f: Povidone-iodine. Medical instruments are decontaminated and sterilized by heat.

Performing dental procedures safely may require the provision of clinics with isolation equipment by negative pressure 


\section{Conclusions}

In the process of infection with SARS- CoV-2, the oral cavity has the role of an entrance gate and a natural barrier, which is overcome by the virulence of this agent, under the conditions of an immune response of the dysfunctional host, incompletely elucidated. The consequences of COVID-19 on the practice of oral medicine are difficult to estimate, but it is obvious that we must learn to protect ourselves and coexist with this virus, waiting for scientific research to discover its secrets and to find effective means of prevention and specific treatment.

\section{References}

1. ***NATI CENTER A NAL OF TRANSMISSIBLE DISEASES. The global situation, updated daily. Available online: URL (accessed on 2020 Mar 24 ) :

https://www.cnscbt.ro/index.php/situatia-la-nivel-global-actualizata-zilnic/1612-situatie-infectiicoronavirus-covid-19-31-03-2020/file .

2. GORBALENYA, AE, BAKER, SC, BARIC, RS . et al. Severe acute respiratory syndrome-related coronavirus species : classifying 2019-nCoV and naming it SARS-CoV2. Nat.. Microbiol. 5, 2020, 536-544; https://doi.org/10.1038/s41564-020-0695-Z .

3. WU, F. ZHAO, S., YU, B. A new coronavirus associated with human respiratory disease in Ch i na. Nature 579, 2020, 265-269 ; https://doi.org/10.1038/s41586-020-2008-3.

4. WAHBA,L. , JAIN , N., Z FIRE , AZ, SHOURA , MS, KAREN,L ARTILES , KL, MCCOY , MJ, JEONG D.E., Identification of a pangolin niche for a $2019 \mathrm{nCoV}$-like coronavirus through an extensive m e ta-metagenomic search. (in press) https://www.biorxiv.org/ content/10. 1101/2020.02. 0939660v2

5. HUANG, C. , LI, X., REN, L., ZHAO, J., HU, Y., Clinical features of patients infected with 2019 novel coronavirus in Wuhan, China. Lancet, 395, 2020, 497-506; https://doi.org/10.1016/S01406736(20)30183-5.

6. MAO L, HUIJUAN JIN, H., WANG; M., Neurologic Manifestations of Hospitalized P a tients With Coronavirus Disease 2019 in Wuhan, China . JAMA Neurol ., 2020 (in print); https:// doi.org /10.1001 / jamaneurol.2020.1127.

7. WORLD HEALTH ORGANIZATION (WHO) Report of the WHO-China Joint Mission on Cor o na virus Disease 2019 (COVID-19) Available online: URL (accessed on 2020 Mar 24 )

https://www.who.int/publications-detail/report-of-the-who-china-jointmission-on-coronavirus-disease2019-(covid-19.

8. NISHIURA, H., KOBAYASHI, T., SUZUKI, A., JUNG, SM, HAYASHI, K., KINOSHITA, R. , Estimation of the asymptomatic ratio of novel coronavirus infections (COVID-19). Int J Infect Dis , 2020 (in print); S1201971220301399; https://doi.org/10.1101/2020.02.03.20020248 .

9. ZHOU , F. Yu , T . DU , R. FAN , G. Liu , Y . Liu , Z . Clinical course and risk factors for mortality of adult inpatients with COVID-19 in Wuhan, China: a retrospective cohort study. Lancet ., 395 (10229), 2020, 1054-1062 ; https: // two. 10.1016 / S0140-6736 (20) 30566-3.

10. GANYANI , T ., KREMER , C . Chen , D ., Torner , A ., FAES , C ., Walling , J ., Estimating the generation interval for COVID-19 based on symptom onset data. medRxiv. 2020 (in print); 2020.03.05.20031815; https://doi.org/10.1101/2020.03.05.20031815 .

11. ZHAO, J., YUAN, Q., WANG, H., LIU, W., LIAO , X., SU, Y., WANG, X., YUAN, J., LI, T., LI, J., QIAN, S., HONG, C., WANG, F., LIU, Y., WANG, Z., HE, Q., LI, Z., HE, B., ZHANG, T., YA N .G. FU , SHENGXIANG GEEI LIU, L., ZHANG, J., XIA, N., ZHANG, Z., Antibody responses to SARS-CoV-2 in patients with novel coronavirus disease 2019, Clin. Inf. Dis, 2020 (in print); ciaa344; https://doi.org/10.1093/cid/ciaa344 .

12. MENG , L . HUA , F ., BIAN , Z . Coronavirus Disease 2019 (COVID-19): Emerging and Future Challenges for Dental and Oral Medicine. J. Tooth. Res . 2020 (n print); https://doi.org/ 10.1177 / $\underline{0022034520914246}$. 
13. KAMPF, G., TODT, D. , PFAENDER, S., STEINMANN, E. Persistence of coronaviruses on i n animate surfaces and their inactivation with biocidal agents. J. Hosp . Infect, 104 (3), 2020 , 246251.

14.LECHIEN, JR, CHIESA-ESTOMBA, CM, DE SIATI, DR et al. Olfactory and gustatory dy $\mathrm{s}$ functions as a clinical presentation of mild-to-moderate forms of coronavirus disease (COVID19): a multicenter European study. Eur Arch Otorhinolaryngol (2020).

https://doi.org/10.1007/s00405-020-05965-1.

15. XU , H . ZHONG , L . DENG , J . PENG , J ., DAN , H . ZENG , X . , High expression of ACE2 rece $\mathrm{p}$ tor of $2019 \mathrm{CoV}$ on the epithelial cells of oral mucosa. Int J Oral Sci., 24, 2020,18. https://doi.org/ 10.1038 / s41368-020-0074-X.

16. OAKES, JM ., FUCHS, RM ., GARDNER, JD ., LAZARTIGUES, E ., YUE, X . Nicotine and the renin-angiotensin system. Am J Physiol Regul Integr Comp Physiol, 315 (5), 2018, 895-906. doi: 10.1152 / ajpregu.00099.2018.

17. BARleAN, M.C., BAlCOS, C., BOBU, L.I., CRETU, C.I., PlatON, A.L., STUPU, A., NICOLAICIUC O., TOPOR G., BEZNEA A., POPESCU E. Microbiological Evaluation of Surgical Site Infections in the Clinic of Oral and Maxillofacial Surgery of the Sf. Spiridon Clinical Hospital in Iasi, Romania. Rev Chim., 70(11), 2019, 4077-4082.

18. BAROIU, L., BEZNEA, A., CONDRATOVICI, C.P., ONISOR, C., GRIGORE, C.A., TOPOR, G., RUGINA, S. Comparative Effectiveness of Vancomycin and Metronidazole for the Initial Episode of Nonsevere Clostridium Difficle Infection. Rev Chim., 70(10), 2019, 3741-3745.

19. EARAR, K., GRIGORE, C.A., BUDACU, C., TRINCA, L.C., MARECI, D., SINCAR, C.D. Electrochemical Behaviour of Titanium Based Biomaterials in Artificial Saliva. Rev Chim., 68(2), 2017, 396-400.

20. TO, K.K., TSANG, A. T., CHIK-YAN YIP C., Consistent detection of 2019 novel coronavirus in sal i va. Clin Infect Dis ., 2020 (in print); https://doi.org/10.1093/cid/ciaa149 .

21. LUPUSORU, R.V., TOPOR, G., MIRON, I.C., GRIGORE, M., ESANU, I. Chemical Factors which Prompt Oral Pathological Phenomena In Some Nutrition Diseases. Rev Chim., 2019; 70(5): 1884-1887.

22. ESANU, I, DEBITA, M, DOROBAT, CM, ILIESCU, AA, MATEI, MN, PALADE, DO, EARAR, K., Chemical and Biological Factors in Infectious Diseases The oral microbial flora. Rev Chim., 2019; 70 (4): 1420-1423.

23.CIOBOTARU, OR, LUPU, MN, REBEGEA, L, CIOBOTARU, OC, DUCA, OM, TATU, AL, VOINESCU, CD, STOLERIU, G, EARAR, K, MIULESCU, M. Dexamethasone - Chemical Structure and Mechanisms of Action in Prophylaxis of Postoperative Side Effects.. Rev Chim., 70(3), 2019, 843847.

24. ***WORLD HEALTH ORGANIZATION . Advice on the use of masks in the community, during home care and in healthcare settings in the context of the novel coronavirus (COVID-19) outbreak. 2020. Available online: URL (accessed on 2020 Mar 20 )

https://www.who.int/publications-detail/ a d vice-on-the-use-of-masks-in-the-communityduring-homecare-and-in-healthcare-settings-in-thecontext- of-the-novel-coronavirus- (2019-ncov) -outbreak . 25.***EUROPEAN CENTER FOR DISEASE PREVENTION AND CONTROL. ECDC TECHNICAL REPORT Interim guidance for environmental cleaning in non-healthcare facilities exposed to SARS-CoV-2 . Available online: URL (accessed on 18 February 2020 ): https://www. ecdc.europa.eu/sites/default/files/documents/coronavirus-SARS-CoV-2-guidance-environmentalcleaning-non-healthcare- facilities.pdf .

$\overline{\text { Manuscript received: } 23.04 .2020}$ 